\title{
Past changes in the North Atlantic storm track driven by insolation
}

\section{and sea-ice forcing}

\author{
Lisa C. Orme ${ }^{1 *}$, Daniel J. Charman ${ }^{1}$, Liam Reinhardt ${ }^{1}$, Richard T. Jones ${ }^{1}$, Fraser J. G. Mitchell ${ }^{2}$, Bettina S. Stefanini ${ }^{3}$, \\ Andrew Barkwith ${ }^{4}$, Michael A. Ellis ${ }^{4}$, and Mark Grosvenor ${ }^{1}$ \\ ${ }^{1}$ Department of Geography, University of Exeter, Amory Building, Rennes Drive, Exeter EX4 4RJ, UK \\ 2Department of Botany, Trinity College Dublin, Dublin 2, Ireland \\ ${ }^{3}$ Department of Geography, Rhetoric House, South Campus, Maynooth University, County Kildare, Ireland \\ ${ }^{4}$ British Geological Survey, Nicker Hill, Keyworth, Nottingham NG12 5GG, UK
}

\begin{abstract}
Changes in the location of Northern Hemisphere storm tracks may cause significant societal and economic impacts under future climate change, but projections of future changes are highly uncertain and drivers of long-term changes are poorly understood. Here we develop a late Holocene storminess reconstruction from northwest Spain and combine this with an equivalent record from the Outer Hebrides, Scotland, to measure changes in the dominant latitudinal position of the storm track. The north-south index shows that storm tracks moved from a southern position to higher latitudes over the past $4000 \mathrm{yr}$, likely driven by a change from meridional to zonal atmospheric circulation, associated with a negative to positive North Atlantic Oscillation shift. We suggest that gradual polar cooling (caused by decreasing solar insolation in summer and amplified by sea-ice feedbacks) and mid-latitude warming (caused by increasing winter insolation) drove a steepening of the winter latitudinal temperature gradient through the late Holocene, resulting in the observed change to a more northern winter storm track. Our findings provide paleoclimate support for observational and modeling studies that link changes in the latitudinal temperature gradient and sea-ice extent to the strength and shape of the circumpolar vortex. Together this evidence now suggests that North Atlantic winter storm tracks may shift southward under future warming as sea-ice extent decreases and the mid- to high-latitude temperature gradient decreases, with storms increasingly affecting southern Europe.
\end{abstract}

\section{INTRODUCTION}

Future climate change scenarios project with low certainty that there will be a northward North Atlantic storm track shift (Collins et al., 2013), which would increase winter storminess in northern Europe. In contrast, it has recently been suggested that Arctic amplification of warming resulting from reduced sea-ice extent could have the opposite effect, causing a reduced latitudinal temperature gradient leading to a weakened circumpolar vortex, more meridional circulation patterns, and persistent weather extremes in the mid-latitudes (Kim et al., 2014; Francis and Vavrus, 2012; Yang and Christensen, 2012). This is an important possibility to consider, as greater than expected economic and societal costs may be incurred if storm tracks shift southward across mainland Europe. Improving understanding of the drivers of changes in storminess is critical to reducing uncertainty. Paleoclimate records can be used to test different hypotheses on relationships between circulation responses and forcing mechanisms such as sea-ice variability.

*Current address: Norwegian Polar Institute, Fram Centre, 9296 Troms $\varnothing$, Norway
Previous research suggests a number of key natural forcings on atmospheric circulation. Modeling shows that orbital changes through the Holocene would have caused a progressively steep temperature gradient and a northward storm track shift (Brayshaw et al., 2010), and some paleoclimate reconstructions have attributed trends in storminess to orbital forcing (Bakke et al., 2008; Orme et al., 2016). However, over shorter annual-centennial time scales, low solar activity, particularly reductions in ultraviolet radiation, has been associated with weakened stratospheric westerly winds that induce negative North Atlantic Oscillation (NAO) anomalies and a southward storm track shift (Ineson et al., 2011; Martin-Puertas et al., 2012). Oceanic forcing has also been suggested as a key driver, whereby greater southward penetration of polar water in the Atlantic may have enhanced the temperature gradient, increasing storm intensity across Europe (Sabatier et al., 2012). Evidence also suggests that reduced sea ice can cause a weakening of the circumpolar vortex and a negative NAO pattern in winter (Kim et al., 2014; Alexander et al., 2004), which would favor a southward storm track shift.
Here we develop a storm track index spanning the late Holocene and use this as the basis to test the dominant drivers of change over this period. We develop storminess reconstructions from two locations at opposite ends of the storm track gradient, reflected in their relationship with the NAO; storminess is greater in Spain when the NAO is negative, and storminess is greater in Scotland when the NAO is positive (see the GSA Data Repository ${ }^{1}$ ). Thus, we can use the difference between these locations as an index of long-term changes in the dominant storm tracks.

\section{METHODS}

Pedrido Bog is an ombrotrophic peat bog in northwest Spain (Fig. 1; $43.4503^{\circ}$ N, $7.5292^{\circ} \mathrm{W}$;

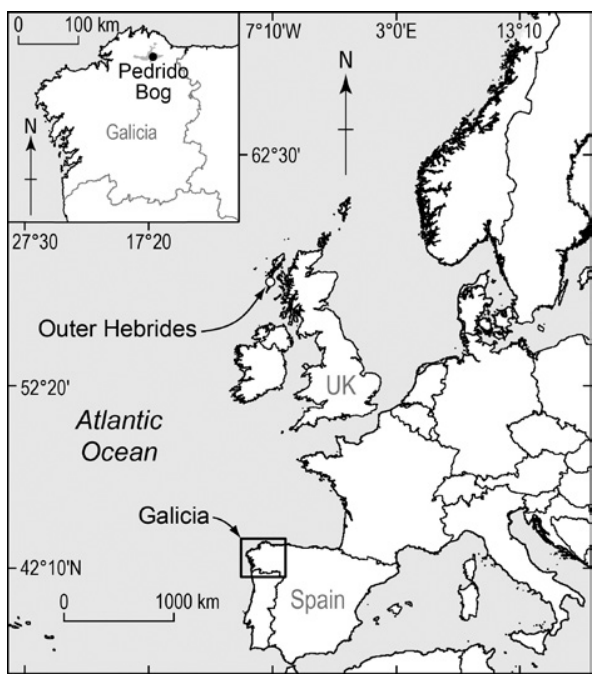

Figure 1. Map illustrating the location of Pedrido Bog in northwest Spain, and storm reconstruction sites from the Outer Hebrides, Scotland (Orme et al., 2016), used to develop the north-south storm track index. Inset: Pedrido Bog location in northwest Spain.

${ }^{1}$ GSA Data Repository item 2017097, study site descriptions, and radiocarbon and ${ }^{210} \mathrm{~Pb}$ dates, is available online at http://www.geosociety.org/datarepository /2017/, or on request from editing@geosociety.org. 


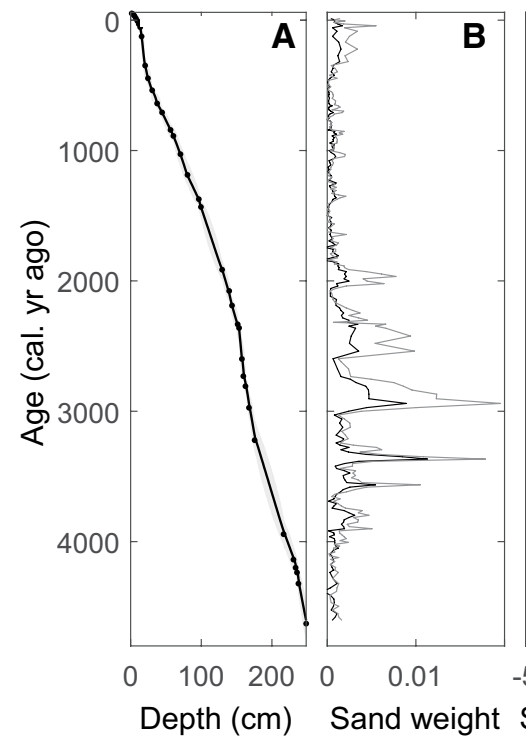

(g)
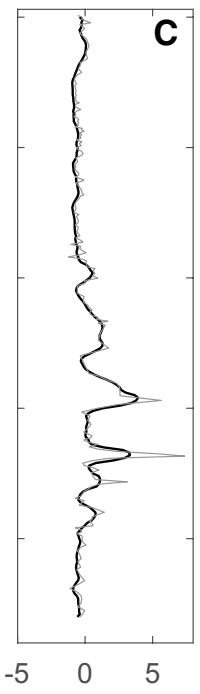

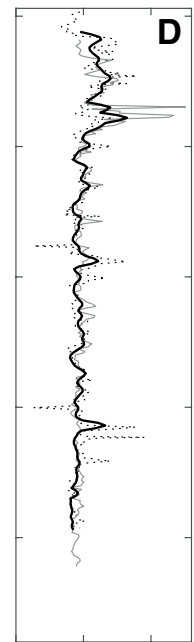

$-5$

Standardized

units

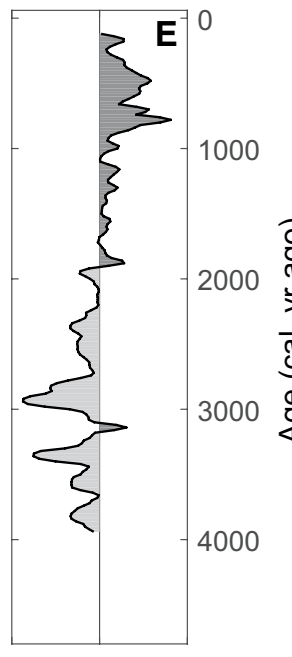

$\begin{array}{lll}-5 & 0 & 5\end{array}$

Standardized

units

Figure 2. Records used to develop the north-south storm track index. A: Age-depth model from Pedrido Bog (Spain) (age estimates in the Data Repository; see footnote 1). B: Sediment content for Pedrido Bog shown as weight of sand fractions $(120-180 \mu \mathrm{m}$, gray line; $>180 \mu \mathrm{m}$, black line). C: Standardized 120-180 $\mu \mathrm{m}$ fraction measurements from plot B (gray line) and smoothed results (black line). D: Standardized sediment influx measurements from two sites in the Outer Hebrides, Scotland (Orme et al., 2016), with the combined reconstruction (black, continuous line). E: North-south index of storm track position, derived from the difference between the smoothed and combined records in $C$ and $D$.

770 m altitude; see the GSA Data Repository). A 2.5-m-long core was sampled using a Russian corer in 2003. Eight samples were ${ }^{210} \mathrm{~Pb}$ dated and 30 samples were radiocarbon dated with accelerator mass spectrometry (AMS; see the Data Repository), and sample ages were estimated using Bayesian analysis in $\mathrm{OxCal}$ version 4.2.3 (Bronk Ramsey, 2009).

In ombrotrophic peat bogs, mineral material can only be received from the atmosphere, therefore measurements of sand content through a peat core can be used as a storminess proxy. The storminess reconstruction was developed from the ignition residue and weight of sand-sized sediment $(120-180 \mu \mathrm{m}$ and $>180 \mu \mathrm{m})$ in $5 \mathrm{~cm}^{3}$ of wet material at $1 \mathrm{~cm}$ increments, following the methods in Orme et al. (2016).

A north-south index of storm track position was calculated by contrasting between sand content from the Pedrido Bog reconstruction and similar reconstructions from the Outer Hebrides (Orme et al., 2016; see the Data Repository). The two Hebrides reconstructions (ignition residue measurements) and the Pedrido reconstruction (120-180 $\mu \mathrm{m}$ sand fraction) were selected because these proxies best represented the sand content in each core. These were standardized, and each smoothed and downsampled to the same $20 \mathrm{yr}$ resolution. The Outer Hebrides results were then averaged together to maximize the regional signal, and the normalized Pedrido reconstruction was subtracted from the combined Hebrides reconstruction.

\section{LATE HOLOCENE STORMINESS IN NORTHWEST SPAIN}

Sediment influx in the Spanish site was significantly greater in the early part of the record between ca. 4 and $1.8 \mathrm{ka}$ than during the past 1.8 k.y. (Fig. 2). There are also a series of peaks in sediment content between 3.9 and $1.8 \mathrm{ka}$ (ca. $3.8,3.55,3.3,2.85,2.4,1.95$, and $0.25 \mathrm{ka}$ ), suggesting that shorter phases of intense storminess were overlain on the multimillennial trend. Greater dust influx during storms could result from human disturbance of soil in the vicinity of the bog. Deforestation occurred throughout much of the late Holocene in northwest Spain, but in general, forest cover is greater before than after 2 ka (Mighall et al., 2006). We thus favor a climatic interpretation as the record compares well with regional climate reconstructions from marine cores, which are likely to be less influenced by anthropogenic changes. For example, there was a strong hydrodynamic regime (prevalent winter storms) at 4.8-2.2 ka (Martins et al., 2007), high terrestrial input (high precipitation) at 4.2-2.1 ka (Pena et al., 2010), and humid conditions at 3.5-1.8 ka (Mojtahid et al., 2013), supporting the interpretation of the Pedrido reconstruction as a record of regional storminess variability.

\section{NORTH-SOUTH STORM TRACK INDEX}

The north-south storm track index (Fig. 2) suggests that there was a more southern storm track ca. $4.0 \mathrm{ka}$, with a transition to a northern storm track occurring over the period 3.0-0.8 ka.

The northward movement of the storm track over the late Holocene is associated with a series of other indicators of ocean circulation and terrestrial climate, including increased winddriven Atlantic Water inflow to the Nordic Sea (Giraudeau et al., 2010; Fig. 3A), increasing storminess in northern Europe (Andresen et al., 2005), and increasing winter precipitation,
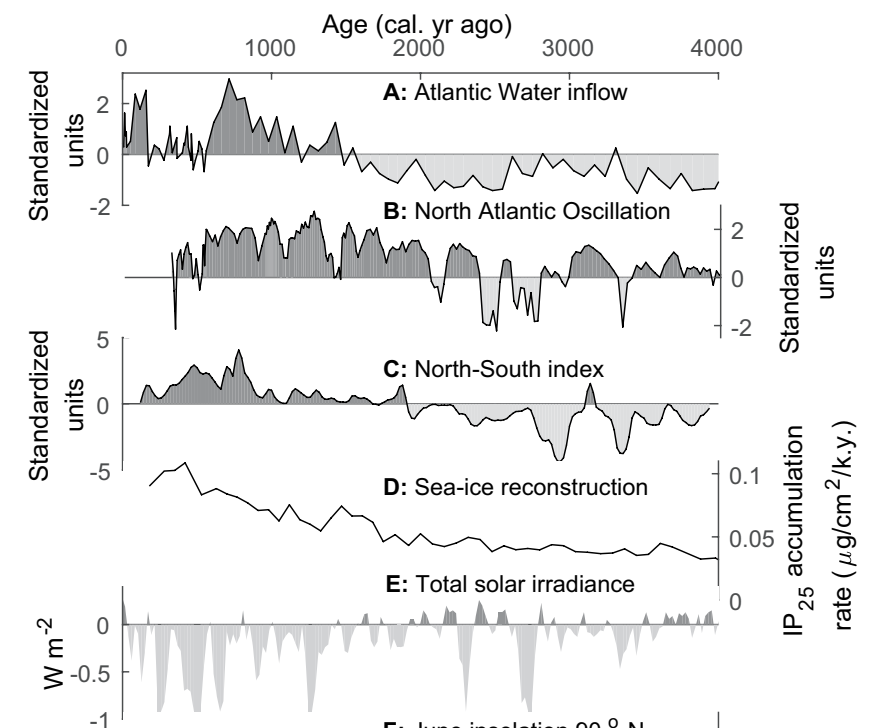

Figure 3. A: Comparison between wind-driven Atlantic Water Inflow (Giraudeau et al., 2010), with key forcings (in D-E). B: Reconstruction of the North Atlantic Oscillation (Olsen et al., 2012) compared with key forcings (in D-E). C: The north-south storm track reconstruction compared with key forcings (in D-E). D: Changes in sea-ice abundance from the Fram Strait (Müller et al., 2012). $I P_{25}$ is an Arctic sea ice biomarker (a lipid derived from sea ice diatoms). E: Total solar irradiance reconstruction (Steinhilber et al., 2012). F: June insolation at $90^{\circ} \mathrm{N}$. $\mathrm{G}$ : December insolation at $60^{\circ} \mathrm{N}$ (Berger and Loutre, 1991), shown to represent the increasing winter temperature gradient between $60^{\circ} \mathrm{N}$ and $90^{\circ} \mathrm{N}$. 
reflected in records of glacial extent in Norway (Bakke et al., 2008). A negative-to-positive NAO transition at $2 \mathrm{ka}$ (Olsen et al., 2012; Fig. 3B) supports the contention that there is a consistent relationship between storminess and the NAO over millennial time scales, although the lower magnitude centennial-scale patterns of NAO variability are debated (Ortega et al., 2015). The long-term movement of the storm track may reflect a change from meridional to zonal circulation of the circumpolar vortex (Bakke et al., 2008); more meridional circulation of the atmosphere between 3.1 and 2.4 ka has also been suggested as a driver of high sea-salt and dust influx in Greenland (O'Brien et al., 1995). Previous suggestions that a cooler North Atlantic and drier continental Eurasia indicate a more negative NAO shift over the late Holocene (Müller et al., 2012) are equally well explained by this circulation change.

The centennial-scale cold events that have punctuated the Holocene are not so clearly shown by the north-south storm track index, despite evidence of more intense storms in Europe during some of these periods, such as the Little Ice Age (Sabatier et al., 2012). Differences in proxy sensitivity may explain this, as reconstructions based on lagoonal sediments record the occurrence of infrequent, highly intense storms when barriers are overtopped, whereas sand deposition to bogs occurs during a wider range of conditions. Lagoonal sediments are also affected by long-term sea-level rise, such that millennialscale trends in storminess are more difficult to establish (Sabatier et al., 2012).

\section{STORM TRACK FORCINGS}

The primary driver of the millennial change in storminess and the winter latitudinal temperature gradient is a shift in orbitally driven solar insolation (Fig. 4). In mid-latitudes $\left(45^{\circ}-60^{\circ} \mathrm{N}\right)$ the winter insolation has increased since $4 \mathrm{ka}$, with December insolation at $60^{\circ} \mathrm{N}$ increasing by $\sim 3 \mathrm{~W} \mathrm{~m}^{-2}$ (Berger and Loutre, 1991; Fig. 3G), although this would have been partially offset by the reductions associated with grand solar minima of $\sim 1 \mathrm{~W} \mathrm{~m}^{-2}$ during periods of decades to centuries (Fig. 3E; Steinhilber et al., 2012; Martin-Puertas et al., 2012). The mid-latitudes therefore would have warmed in winter over the past $4000 \mathrm{yr}$.

In contrast to warming winters at mid-latitudes, orbital changes drove a decrease in summer insolation of $\sim 17 \mathrm{~W} \mathrm{~m}^{-2}$ at $90^{\circ} \mathrm{N}$ since $4 \mathrm{ka}$ that would have had an especially strong influence, because in the polar regions summer insolation is a much greater proportion of the total insolation (Berger and Loutre, 1991; Fig. 3F). This, plus the effect of decreasing solar activity (Steinhilber et al., 2012; Fig. 3E), is likely to have caused the decrease in Arctic temperatures through the late Holocene, as shown by ice-core and marine archives (Alley, 2004; Kim
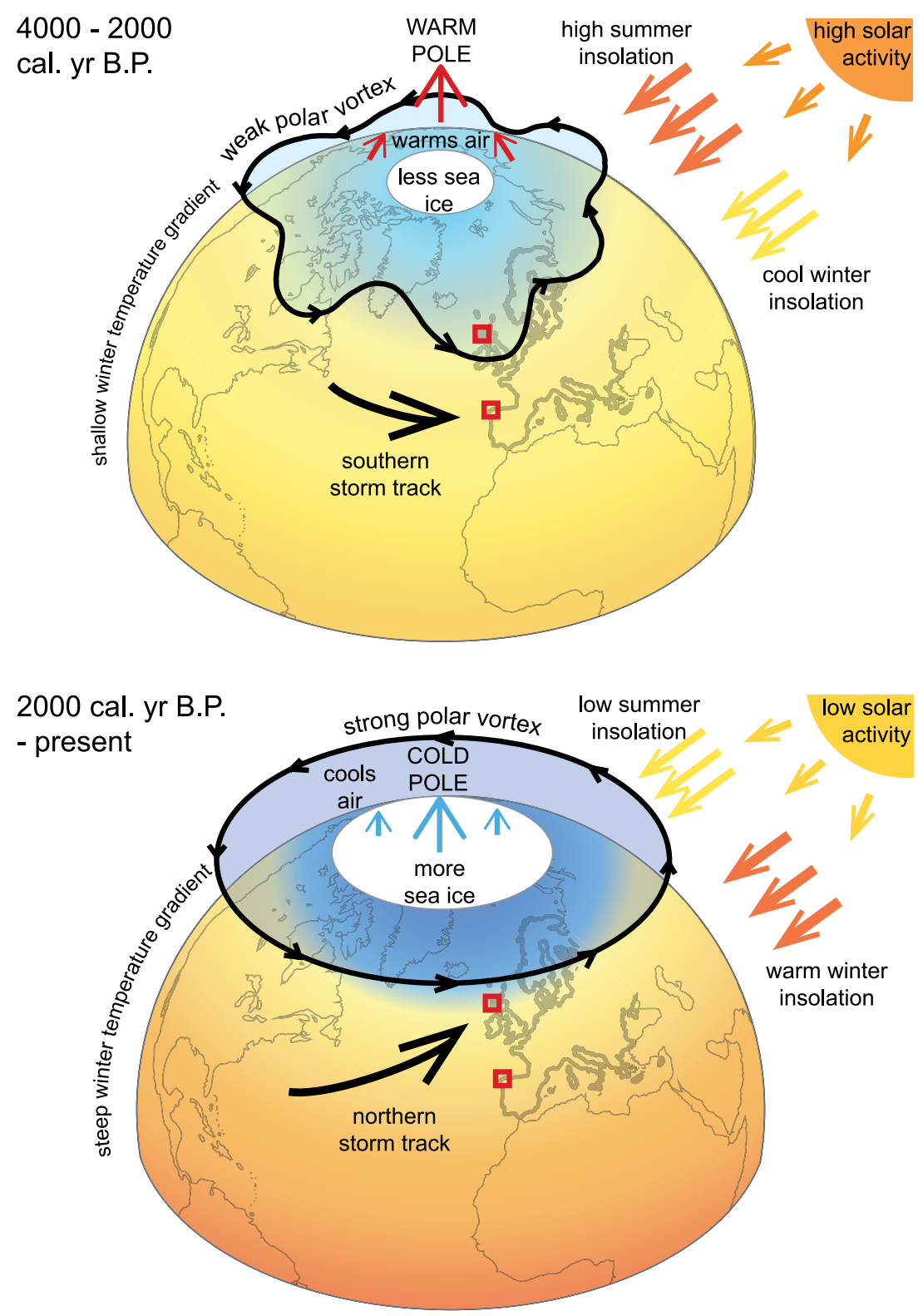

Figure 4. Schematic summary of the relationship between atmospheric circulation and climate forcings. These represent the idealized circulation patterns and longterm trends, rather than centennial variability in circulation.

et al., 2004). Summer cooling also caused more extensive sea-ice formation, especially after ca. 2 ka (Müller et al., 2012; Vare et al., 2009; Fig. 3D). Sea ice provides a mechanism through which the summer insolation would have influenced winter temperatures, because low sea-ice extent and formation enhance the heat flux from the ocean to the atmosphere, and high sea-ice extent and formation reduce the heat flux, particularly in winter (Alexander et al., 2004). Therefore, before ca. 2 ka, higher insolation in Arctic summers would have caused low sea-ice extent and winter warming, and decreasing summer insolation after 2 ka enhanced sea-ice extent, resulting in gradual winter cooling of the atmosphere (Fig. 4).

The findings support the hypothesis that a combination of decreasing Arctic summer insolation (with ensuing sea-ice feedbacks leading to winter cooling) and orbitally driven mid-latitude winter warming caused a gradual steepening of the latitudinal temperature gradient between the mid- to high latitudes during the late Holocene. This would have strengthened the polar vortex and driven a change from meridional to more zonal circulation and a northward shift in the storm track observed in the north-south index (Fig. 4). This proposed millennial-scale trend and dynamic explanation does not exclude the possibility of decadal-centennial changes driven by solar variability (e.g., Martin-Puertas et al., 2012) that were superimposed on this long-term shift.

\section{FUTURE CIRCULATION CHANGES}

Our results thus provide paleoclimate evidence that supports predictions that future Arctic amplification of warming and sea-ice reductions 
have the potential to reduce the latitudinal temperature gradient (with greater warming in the poles than the mid-latitudes), resulting in meridional circulation and higher storminess in southern Europe (Francis and Vavrus, 2012; Kim et al., 2014) rather than a northward storm track shift (Collins et al., 2013). Models have also suggested that sea-ice reductions lead to negative NAO circulation patterns (Yang and Christensen, 2012), supporting the link between the hypothesized storminess trend and the NAO.

However, the circulation response to global warming is likely to be modified by a range of factors. Model simulations demonstrate that weakening of Atlantic Ocean circulation causes cooling to the south of Greenland and a steeper temperature gradient south of the British Isles, which shifts the storm track farther south (Woollings et al., 2012). Furthermore, models that incorporate the stratosphere have shown that increased strength of the Brewer-Dobson circulation leads to a southward-shifted polar night jet stream, greater eddy growth in the mid-latitudes, and enhanced storminess in western and central Europe (Scaife et al., 2012). These factors may therefore further strengthen the trend toward greater storminess in southern Europe.

If correct, the findings presented here have important implications for assessments of future climate impacts and necessary adaptation measures in Europe, raising the risk of environmental, societal, and economic damage in different regions to those currently thought to be most at risk.

\section{ACKNOWLEDGMENTS}

Orme was funded by the University of Exeter and a British Geological Survey University Funding Initiative (BUFI) Studentship. We are grateful to the ACCROTELM (Abrupt Climate Changes Recorded over the European Land Mass) Project, supported by European Commission Contract EVK2-CT-2002-00166, for contributing the dated Pedrido Bog core.

\section{REFERENCES CITED}

Alexander, M.A., Bhatt, U.S., Walsh, J.E., Timlin, M.S., Miller, J.S., and Scott, J.D., 2004, The atmospheric response to realistic Arctic sea ice anomalies in an AGCM during winter: Journal of Climate, v. 17, p. 890-905, doi:10.1175/1520 -0442(2004)017<0890:TARTRA>2.0.CO;2.

Alley, R.B., 2004, GISP2 ice core temperature and accumulation data: IGBP PAGES/World Data Center for Paleoclimatology, Volume Data Contribution Series \#2004-013: Boulder, Colorado, National Oceanic and Atmospheric Administration National Geophysical Data Center Paleoclimatology Program, ftp://ftp.ncdc.noaa.gov /pub/data/paleo/icecore/greenland/summit/gisp2 /isotopes/gisp2_temp_accum_alley2000.txt.

Andresen, C.S., Bond, G., Kuijpers, A., Knutz, P.C., and Björck, S., 2005, Holocene climate variability at multidecadal time scales detected by sedimentological indicators in a shelf core NW off Iceland: Marine Geology, v. 214, p. 323-338, doi:10.1016/j.margeo.2004.11.010.

Bakke, J., Lie, Ø., Dahl, S.O., Nesje, A., and Bjune, A.E., 2008, Strength and spatial patterns of the Holocene wintertime westerlies in the NE Atlantic region: Global and Planetary Change, v. 60, p. 2841, doi:10.1016/j.gloplacha.2006.07.030.

Berger, A., and Loutre, M.-F., 1991, Insolation values for the climate of the last 10 million years: Quaternary Science Reviews, v. 10, p. 297-317, doi: 10.1016/0277-3791(91)90033-Q.

Brayshaw, D., Hoskins, B., and Black, E., 2010, Some physical drivers of changes in the winter storm tracks over the North Atlantic and Mediterranean during the Holocene: Royal Society of London Philosophical Transactions, ser. A, v. 368, p. 5185-5223, doi:10.1098/rsta.2010.0180.

Bronk Ramsey, C., 2009, Bayesian analysis of radiocarbon dates: Radiocarbon, v. 51, p. 337-360, doi: $10.1017 /$ S0033822200033865.

Collins, M., Knutti, R., Arblaster, J., Dufresne, J.-L., Fichefet, T., Friedlingstein, P., Gao, X., Gutowski, W., Johns, T., and Krinner, G., 2013, Long-term climate change: Projections, commitments and irreversibility, in Stocker, T., et al., eds., Climate change 2013: The physical science basis. Contribution of Working Group I to the Fifth Assessment Report of the Intergovernmental Panel on Climate Change: Cambridge, UK, Cambridge University Press, p. 1029-1136, doi:10.1017 /CBO9781107415324.024.

Francis, J.A., and Vavrus, S.J., 2012, Evidence linking Arctic amplification to extreme weather in midlatitudes: Geophysical Research Letters, v. 39, L06801, doi:10.1029/2012GL051000.

Giraudeau, J., Grelaud, M., Solignac, S., Andrews, J.T., Moros, M., and Jansen, E., 2010, Millennialscale variability in Atlantic water advection to the Nordic Seas derived from Holocene coccolith concentration records: Quaternary Science Reviews, v. 29, p. 1276-1287, doi:10.1016/j .quascirev.2010.02.014.

Ineson, S., Scaife, A.A., Knight, J., Manners, J., Dunstone, N., Gray, L., and Haigh, J., 2011, Solar forcing of winter climate variability in the Northern Hemisphere: Nature Geoscience, v. 4, p. 753-757, doi:10.1038/ngeo1282.

Kim, B.-M., Son, S.-W., Min, S.-K., Jeong, J.-H., Kim, S.-J., Zhang, X., Shim, T., and Yoon, J.-H., 2014, Weakening of the stratospheric polar vortex by Arctic sea-ice loss: Nature Communications, v. 5, p. 4646, doi:10.1038/ncomms5646.

Kim, J.-H., Rimbu, N., Lorenz, S.J., Lohmann, G., Nam, S.-I., Schouten, S., Rühlemann, C., and Schneider, R.R., 2004, North Pacific and North Atlantic sea-surface temperature variability during the Holocene: Quaternary Science Reviews, v. 23, p. 2141-2154, doi:10.1016/j.quascirev.2004 .08 .010 .

Martin-Puertas, C., Matthes, K., Brauer, A., Muscheler, R., Hansen, F., Petrick, C., Aldahan, A., Possnert, G., and van Geel, B., 2012, Regional atmospheric circulation shifts induced by a grand solar minimum: Nature Geoscience, v. 5, p. 397-401, doi:10.1038/ngeo1460.

Martins, V., Dubert, J.S., Jouanneau, J.-M., Weber, O., da Silva, E.F., Patinha, C., Alveirinho Dias, J.O.M., and Rocha, F., 2007, A multiproxy approach of the Holocene evolution of shelf-slope circulation on the NW Iberian Continental Shelf: Marine Geology, v. 239, p. 1-18, doi:10.1016/j margeo.2006.11.001.

Mighall, T., Cortizas, A.M., Biester, H., and Turner, S., 2006, Proxy climate and vegetation changes during the last five millennia in NW Iberia: Pollen and non-pollen palynomorph data from two ombrotrophic peat bogs in the north western Iberian Peninsula: Review of Palaeobotany and Palynology, v. 141, p. 203-223, doi:10.1016/j .revpalbo.2006.03.013.

Mojtahid, M., Jorissen, F., Garcia, J., Schiebel, R., Michel, E., Eynaud, F., Gillet, H., Cremer, M., Diz Ferreiro, P., and Siccha, M., 2013, High resolution Holocene record in the southeastern Bay of Biscay: Global versus regional climate signals: Palaeogeography, Palaeoclimatology, Palaeoecology, v. 377 , p. $28-44$, doi:10.1016/j palaeo.2013.03.004.

Müller, J., Werner, K., Stein, R., Fahl, K., Moros, M., and Jansen, E., 2012, Holocene cooling culminates in sea ice oscillations in Fram Strait: Quaternary Science Reviews, v. 47, p. 1-14, doi: 10.1016/j.quascirev.2012.04.024.

O'Brien, S.R., Mayewski, P.A., Meeker, L.D., Meese, D.A., Twickler, M.S., and Whitlow, S.I., 1995, Complexity of Holocene climate as reconstructed from a Greenland Ice Core: Science, v. 270 , p. $1962-1964$, doi:10.1126/science. 270 .5244 .1962 .

Olsen, J., Anderson, N.J., and Knudsen, M.F., 2012, Variability of the North Atlantic Oscillation over the past 5,200 years: Nature Geoscience, v. 5, p. 808-812, doi:10.1038/ngeo1589.

Orme, L.C., Reinhardt, L., Jones, R.T., Charman, D.J., Barkwith, A., and Ellis, M.A., 2016, Aeolian sediment reconstructions from the Scottish Outer Hebrides: Late Holocene storminess and the role of the North Atlantic Oscillation: Quaternary Science Reviews, v. 132, p. 15-25, doi: 10.1016/j.quascirev.2015.10.045.

Ortega, P., Lehner, F., Swingedouw, D., Masson-Delmotte, V., Raible, C.C., Casado, M., and Yiou, P., 2015, A model-tested North Atlantic Oscillation reconstruction for the past millennium: Nature, v. 523, no. 7558, p. 71-74, doi:10.1038 /nature 14518

Pena, L., Francés, G., Diz, P., Esparza, M., Grimalt, J.O., Nombela, M., and Alejo, I., 2010, Climate fluctuations during the Holocene in NW Iberia: High and low latitude linkages: Continental Shelf Research, v. 30, p. 1487-1496, doi:10.1016/j.csr 2010.05.009.

Sabatier, P., Dezileau, L., Colin, C., Briqueu, L., Bouchette, F.R., Martinez, P., Siani, G., Raynal, O., and Von Grafenstein, U., 2012, 7000 years of paleostorm activity in the NW Mediterranean Sea in response to Holocene climate events: Quaternary Research, v. 77, p. 1-11, doi:10.1016/j .yqres.2011.09.002.

Scaife, A.A., et al., 2012, Climate change projections and stratosphere-troposphere interaction: Climate Dynamics, v. 38, p. 2089-2097, doi:10 .1007/s00382-011-1080-7.

Steinhilber, F., Abreu, J.A., Beer, J.R., Brunner, I., Christl, M., Fischer, H., Heikkilä, U., Kubik, P.W., Mann, M., and McCracken, K.G., 2012, 9,400 years of cosmic radiation and solar activity from ice cores and tree rings: National Academy of Sciences Proceedings, v. 109, p. 5967-5971, doi: 10.1073/pnas.1118965109.

Vare, L.L., Massé, G., Gregory, T.R., Smart, C.W., and Belt, S.T., 2009, Sea ice variations in the central Canadian Arctic Archipelago during the Holocene: Quaternary Science Reviews, v. 28, p. 1354-1366, doi:10.1016/j.quascirev.2009.01.013.

Woollings, T., Gregory, J.M., Pinto, J.G., Reyers, M., and Brayshaw, D.J., 2012, Response of the North Atlantic storm track to climate change shaped by ocean-atmosphere coupling: Nature Geoscience, v. 5, p. 313-317, doi:10.1038/ngeo1438.

Yang, S., and Christensen, J.H., 2012, Arctic sea ice reduction and European cold winters in CMIP5 climate change experiments: Geophysical Research Letters, v. 39, L20707, doi:10.1029 /2012GL053338.

Manuscript received 24 August 2016

Revised manuscript received 14 December 2016

Manuscript accepted 16 December 2016

Printed in USA 